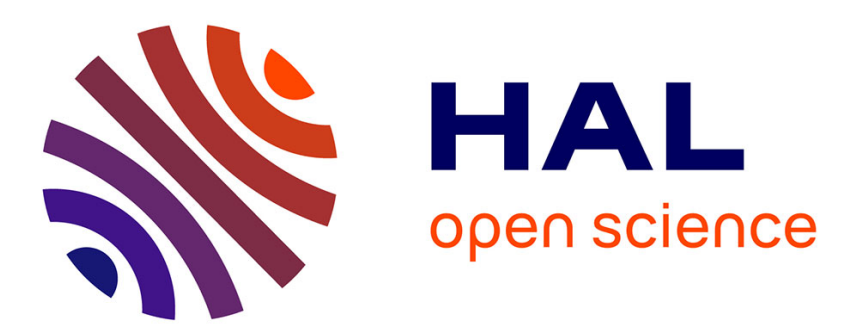

\title{
Micromorphological Study of Construction Materials and Living Floors in the Medieval Motte of Werken (West Flanders, Belgium)
}

Anne Gebhardt, Roger Langohr

\section{- To cite this version:}

Anne Gebhardt, Roger Langohr. Micromorphological Study of Construction Materials and Living Floors in the Medieval Motte of Werken (West Flanders, Belgium). Geoarchaeology: An International Journal, 1999. hal-02273354

\section{HAL Id: hal-02273354 \\ https://hal.science/hal-02273354}

Submitted on 28 Aug 2019

HAL is a multi-disciplinary open access archive for the deposit and dissemination of scientific research documents, whether they are published or not. The documents may come from teaching and research institutions in France or abroad, or from public or private research centers.
L'archive ouverte pluridisciplinaire HAL, est destinée au dépôt et à la diffusion de documents scientifiques de niveau recherche, publiés ou non, émanant des établissements d'enseignement et de recherche français ou étrangers, des laboratoires publics ou privés. 


\title{
Micromorphological Study of Construction Materials and Living Floors in the Medieval Motte of Werken (West Flanders, Belgium)
}

\author{
Anne Gebhardt1 and Roger Langohr2 \\ 1 UMR6566 (Civilisations Atlantiques et Arche'osciences), Campus de Beaulieu, \\ Universite' de Rennes 1, 35042 Rennes Cedex, France \\ 2 University of Gent, Earth Science Institute, Soil Science, Krijgslaan 281/S8, \\ 9000 Gent, Belgium
}

\begin{abstract}
The "Hoge Andjoen," an early medieval motte (860-960 A.D.) is an artificial hill made up of at least eight man-made "ground raising/leveling” layers. Each layer is associated with a stabilization level and a well-preserved occupation surface with evidence such as living floors, traces of cultivation, and goat/sheep trampling. The presence of this hill generated a local rise in the original groundwater table present in the natural, buried soil of the site. In some parts of the hill, and with little relation to the sedimentary boundaries, this process generated permanent water stagnation with pronounced anaerobic conditions and locally strong gradients of oxidoreduction. These gradients created a series of particular migrations and accumulations of iron, manganese, and phosphorus components. All organic artifacts, such as oak posts, wooden floors, leather, and seeds remained well preserved in the strongly reduced parts of the hill; they are completely decayed in the aerated zones of the hill. The soil moisture regime within the motte further influenced a series of postdepositional migrations/accumulations of clay and organic matter. The micromorphological study of this archaeological site allows verification of hypotheses developed during field surveying. These hypotheses relate mainly to the origin and mode of dumping of the various types of earthy material, the human activities related to the nine successive living floors, and the traces of numerous postdepositional processes observed throughout this archaeological structure.
\end{abstract}

\section{INTRODUCTION}

The "Hoge Andjoen” Medieval Motte (Werken, West Flanders, Belgium; Figure 1) is a flat artificial hill about $6 \mathrm{~m}$ in height and $50 \mathrm{~m}$ in base diameter (Figure 2), surrounded by a ditch several meters wide (Figure 3[a]). The site is constructed on the boundary between the occasionally inundated Holocene polder area and the upland with Weichselian coversands resting on a Tertiary sandy to clayey substratum (Figure 1). The archaeological excavation (Vanthournout, 1991) revealed a complex stratigraphy of successive layers. On the basis of the field investigations, eight construction phases (CP1-8) and nine occupation layers (OL1-9) (Figure 3[b]) can be identified. The total occupation and raising of the site lasted approximately 1 century (860-960 A.D.).

The purpose of this micromorphological study is threefold:

1. To characterize further the various features, such as types of earth and types of occupation layers described during the field study (Langohr, 1991).

2. To test the various hypotheses formulated during the macromorphological study. These concern mainly the origin of the earth used to construct the hill and the human activities related to the occupation layers.

3. To study further the various characteristics related to diagenetic pedogenetic processes.

\section{MATERIALS AND METHODS}

Bulk soil samples and undisturbed clods were collected throughout the whole pedolithostratigraphic sequence of the hill. The microscopical description of the about 20 medium (6 $39 \mathrm{~cm}$ ) and 20 small (petrographic-type) thin sections followed the terminology of Bullock et al. (1985). As some accumulated substances could not be identified with sufficient precision through the optical microscope, complementary analysis was carried out by microprobe analysis with a Jeol 6400.

\section{RESULTS}

The field and microscopic data of the most characteristic layers and features are summarized in Tables I-IV. Table I provides basic data of the two upland soil types from which earth was extracted for the construction of the Motte. The Polder soil is described on the basis of large fragments that were recovered in an area where the first three construction layers (CP1, 2, and 3) border the polder area. The Low Upland Soil was sampled in situ under the motte, in the area bordering the northern part of the ditch. The information on the High Upland soil is based on the characteristics of large clods of earth deposited in successive layers at the level of the fifth and sixth construction layers (CP5 and CP6b). The main field and microscopic characteristics of the construction layers and of the occupation levels are provided in Table II. The data on the anthropogenic and diagenetic features are described in Tables III and IV.

\section{INTERPRETATION AND DISCUSSION}

\section{The Construction Phases}

The field observations revealed that the earth used to raise the hill surface came from three soil-geomorphic areas:

1. the polder area (Figure 1), closely surrounding the site to the NW, W and SW;

2. the lower upland area, surrounding the site within 50-100 m to the N, E, and SE (not distinguished on Figure 1

because of scale);

3. the higher upland area (Figure1) at a distance of more than 50-100 $\mathrm{m}$ to the N, E, and SE. 
The earth of the first two construction phases (CP1 and CP2) was extracted from the gradual widening and deepening of the ditch surrounding the site. As the site is situated just on the margin between the polder and the low upland, two types of sediment may be distinguished.

1. The sediment of the polder area (CP1) was extracted from the ditch situated on the southern and western side of the motte. This earth is dark-colored and contains numerous grayish clay fragments and organic remains. Micritic crystallizations are often observed in the porosity or around isolated clay fragments. These crystals were found within the polder clay sediment. Local concentrations in CP1 of whole mussel shells, in various positions, indicate the sudden dumping of material related to the construction of the motte surface, rather than a gradual accumulation of domestic waste. This is confirmed by the presence of clay with microscopic small shells, diatoms (Figure 4), sea-urchin needle fragments and some humiferous sediment inside the shells. All these features confirm that these empty shells were first thrown in the ditch bordering the polder. Later, when they were completely filled with polder sediments and other material originating from the ditch bottom, they were extracted and dumped with the rest of the ditchfill on the motte surface.

2. The earth extracted from the northern and eastern side of the ditch (Table I - Low Upland Soil) is uniformly fine to very fine, sandy, and dominantly light colored, but includes humic fragments similar to the homogeneous, dark-colored original surface Ap horizon of the Psammaquent (Soil Survey Staff, 1998) or Gleysol (FAO, 1998) that can be observed buried under the motte (OF1). The micromorphological observations show the presence of plant and peat remains (Figure 5), which points to the separate dumping of humiferous and peaty material, as opposed to regular additions of humus-rich material, constantly mixed by farming activities. Therefore, in order to place the better earth on top, first the mineral, organic-poor material from the deeper part of the soil was dumped, and in a second phase it was covered by the humus-rich surface material that had been kept separate when starting to dig the ditch. The next construction phases CP2, CP3, and CP4 are very similar to CP1. Each time, the earth was extracted from the increasingly widened and deepened ditch surrounding the site. However, during these three phases, no care was taken to spread the humus-rich earth on top of the dumped material. The material used for raising the motte level during CP5 is clearly different from all the previous phases. Here, identifiable layers can be related to the successive horizons of a Glossudalf (Soil Survey Staff, 1998) or Albeluvisol (FAO, 1998). Such soil type is dominant on the higher upland positions, $\mathrm{N}$ and NE of the motte. A distinction can be made (Table I-High Upland Soil) among the dumped earth between clods of a humic A horizon, a light-colored clay-eluvial E horizon, a brownish finer textured Bt horizon, and a more sandy $\mathrm{C}$ horizon with greenish mottles. The micromorphology shows that here the original A horizon comes from a cropland or a meadow: The soil is very uniform and the organic matter coats the skeletal grains. In the case of a forested site, we would expect the characteristics of the "salt and pepper" humus type in these acid soils, that is, the presence, side by side, of organic pellets and bleached sand grains. The clods of the B horizon contain well-developed ferriargilans. The thin section of the $\mathrm{C}$ horizon fragments shows the presence of abundant glauconitic sand grains, a common feature in the Tertiary upland substratum. This material can therefore be considered to have come from a 2C horizon. CP6 is limited to the central part of the motte, just beside the house. Probably as a result of water excess (drainage from the house roof?), the motte surface here has undergone some degree of subsidence. In order to maintain a more or less flat surface, one to two leveling phases are observed. The material used for this very limited construction phase is sandy with some glauconitic clay inclusions, and thus seems to correspond to the Tertiary soil substratum (2C horizon) of the upland area. The earth dumped during CP7 also comes from the upland Albeluvisol, and fragments of A, $\mathrm{E}, \mathrm{Bt}$, and 2C horizons are recognized in the field. However, three successive subphases are observed in this construction period. First, an outer earth wall was constructed (CP7a) with mixed, very small A, E, Bt, and 2C horizon fragments. The origin of these fragments is confirmed by micromorphological observations. No evidence of intentional strong compaction can be observed in thin sections. This construction is followed by a nonconstruction period during which at least 26 rain showers occurred, as evidenced by a finely stratified sheet-wash deposit at the inner footslope of the earth wall (CP7b). Under the microscope, this deposit is composed of sharp, thin coarse and fine sandy layers. It is evident that the microlayers are not related to clay and/or organic matter migrations as observed in other parts of the hill. However, irregular postdepositional thin Fe-P accumulations are observed in the thin section. These accumulations do not follow the sediment stratification.

The very wet environmental conditions evidenced by the sheet wash deposits may explain the numerous fibrous clayaccumulation bands observed in the earth wall of CP7a. Under the microscope, these features show dusty clay coatings. The third and last subphase (CP7c) corresponds to the dumping of coarse fragmented soil material, leveling the motte surface between the outer earth wall and the house that had been constructed in the meantime. This sediment is composed of much larger fragments of the same Albeluvisol soil type from the upland area. This earth was probably dumped by carts, apparently with no special care taken to crush the earth clods. The origin of the earth used during construction phase CP8 is very difficult to trace in the field. Indeed, several centuries of very active bioturbation, mainly due to earthworms and moles, have homogenized the original dumped earth. The microscopic observations reveal the presence of rounded sand grains, glauconite grains, a matrix very poor in silt and clay, and the absence of diatoms. These characteristics point to an upland origin of the earth.

\section{The Occupation Layers (OL)}

The stability phases are characterized by perfectly preserved occupation layers related to various animal and human activities. These horizons show macroscopical evidence of:

1. cultivation, 
2. puddling by large cattle,

3. trampling by small animals (possibly sheep and/or goats),

4. dwelling construction in the habitat area of the platform, with wooden floors, post holes, animal bone remains, and so on (Vanthournout, 1991).

The field and microscopic data show that both OL1 and OL2 are very similar (Table II). Both horizons are remarkably continuous throughout the site, only interrupted by very large oak postholes used to construct the later dwelling above the ground.

In thin sections, these horizons seem to be very similar to the ploughed layer observed in the black Plaggen soils from the Belgian Kempen (Gebhardt, unpublished EEC Report, 1993; Bastiaens and Van Marik, 1994; Bastiaens, 1994), or the Netherlands (Pape, 1970). Those soils were manured with a mixture of soil material and high amounts of organic matter (Figure 6) containing urine and excrement from the cattle byre. Coarse charcoal fragments are abundant at the top of the layer, but rare or absent at the bottom. Among the largest pieces, charcoal analyst D. Marguerie (personal communication; 1995) could identify small fragments of Corylus and coarse fragments of Quercus, Corylus (Figure 7), and Castanea.

The strong homogeneity and the high amount of organic matter of OL1 and OL2 most probably resulted from permanent cultivation due to intensive fertilization. At least part of the earth and organic matter comes from the deepening and enlarging of the ditch surrounding the hill. The use of ditch sediments as fertilizer in addition to animal manure was common in the Netherlands from Medieval times until the 19th century (Bakels, 1988).

The Chrysophyceae statospores observed in OL1 and OL2 develop in conditions of high humidity (Deflandre, 1936) and may become concentrated by anthropic agricultural activities (Brochier, 1995). They occur here in association with spores, pollen, and abundant, sometimes articulated phytoliths.

The very dense heterogeneous clay fragments (Table I) with elongated parallel voids include slightly charred plant remains (Figure 8). These fragments are too rough to be interpreted as pottery sherds. They resemble pieces of experimental daub made of loam, sand, reed leaves, and water (A. Gebhardt, personal collection).

When subjected to intense burning, charred vegetal fragments disappear, leaving an open porosity in the clasts. The absence of these characteristics shows that the daub fragments were only slightly burnt. Glasslike slag (Table III; Figure 9 ) is often found scattered in open-air archaeological sites. Associated with combustion features, this seems to result from the melting of silicate (Youngblood et al., 1978). In our case, no quartz grains are affected and thus can be interpreted as melted biogenic opal from phytoliths (Velain, 1878; Courty et al., 1989; Gebhardt, 1994, 1995; Gebhardt et al., 1995.). Under ultraviolet light they show a chemical weathering rim of autofluorescent wavellite (Al6(F,OH)6(PO4)-9H2O; B. Van Vliet, personal communication, 1995). At Pottern (GB), microprobe analysis of similar material revealed hydroxyapatite (P-Ca; Macphail and Cruise, in press). The occupation phases OL3-OL5 (Table II) correspond to a farmyard system (Table III), with evidence of compression, trampling, and slight puddling of small cattle. There are no traces of worms or moles, nor particular darkening of the surface layer by humiferous compounds.

OL3, besides a strong mixing of organic fragments as in OL1, has a contrasting, very pellety groundmass and a distinct sorting of the coarse/fine sand fraction (Figure 10), sometimes following the "wavy" orientation. These features reflect the welding and sorting of the layer consistent with the pressures applied by animal hooves on a wet soil. The pyrite formation (Table IV) observed in the trampled upper part, indicates strong local reducing conditions. Certainly, both water saturation in the traffic pan and intense microbiological activity associated with the animal excrements contributed to these intense anoxic conditions.

Thin sections of these occupation layers show abundant diatoms. As these levels contain very little polder clay, the presence of these organisms can probably be related to cattle urine and/or excrement.

OL4 is slightly less pellety and OL5 is less organic, except for some dark Fe-P organic coatings and impregnations (Table II).

OL6 is a thinner, very organic and dark surface horizon (Table II) with a particularly high amount of Fe-P accumulations and humic fragment accumulations just at the base.

OL7 has a fine sand fraction, except near the house, where coarse quartz sand, clayey dusty accumulations, fine charcoal and organic residues occur in undulating, fine strata, probably as a result of puddling.

OL8 was interpreted in the field as a ploughed layer. Under the stereomicroscope, we observed numerous microscopic charcoal, pot sherds, and bone fragments. These inclusions, in association with the absence of mole galleries, confirm the intensive fertilization of a plot probably devoted to horticulture.

The upper and present-day occupation layer OL9 of the motte appears as a 50- cm thick, very dark grayish brown horizon with an irregular lower boundary. The latter characteristic is due to deep, intensive bioturbation by earthworms and moles. The deeper, yellowish brown horizon is rather uniform, with some locally undisturbed fragments of the original dumped earth. On the slope position, OL9 has, in addition, a series of clay-humus accumulation bands that are more or less parallel to the soil surface. Under the microscope, OL9 appears to be the highly organic upper part of a grassland soil, with well-developed pellety pedality, fine fresh roots in biogalleries, and abundant phytoliths. The lower part of the horizon is much less organic. Under the microscope, the illuviation bands appear to be iron-phosphate impregnations and not clay-humus accumulations. This process is expected in a reducing environment. Such conditions may occasionally occur in very rainy periods and are probably favored by the compression of the surface 
horizon of the meadow by cattle trampling. This is the first time we have recorded this iron-phosphate migration in bands. It usually forms mottles of an olive color, and in extreme reducing conditions, reveals white vivianite concentrations which become bluish upon oxidation.

\section{Fireplaces}

At the level of OL6 and OL7, there is a succession of two hearths inside the dwelling area. Both are made of two very dark fine layers with reddish parts, overand underlying a layer composed of mixed, crushed polder clay.

The upper fireplace is made of a layer of burnt polder clay, including big clods of reddish clay, diatoms, and large fragments of charcoal. This layer overlaps an accumulation of highly organic burned peaty clay which, according to the microscopic observation, contains glass slag, charcoal fragments, iron/phosphate accumulations, and oxidized vivianite accumulations. The lower fireplace layer seems to have been disturbed after its use, and is scattered over the surface of the floor. It is very rich in generally charred, connected twig fragments and abundant glass slag. Under this charred layer can be seen small reddish mammillated droplets, probably iron.

\section{Wooden Floor}

At level OL2, a wooden floor was observed within the dwelling area. This floor is cut by an oblique postdepositional iron-manganese crust that developed at the limit of the permanently reduced inner part of the hill (see later). As a consequence, we can observe the wooden floor as it is preserved, within a distance of a few centimeters, in oxidizing and reducing conditions. The floor has been deposited on a sandy subsoil, very poor in groundmass. In the reduced part, the wood is rather well preserved, although it looks charred. D. Marguerie (personal communication, 1995) determined only oak wood, probably coming from one single part of a tree trunk. The micromorphology shows here the association of vivianite, pyrite, and siderite (Table IV; Gebhardt and Langohr, 1996). Where oxidized, the floor is only recognizable through very dusty accumulations in the sandy sediment (Figure 11), without any preserved charcoal, as would be expected in the case of burning. It is not clear whether the dusty aspect of the material comes from the dust which fell through the wooden boards, or from the floor alteration. It can be concluded that the charred aspect in the reduced area does not correspond to fire, but is simply related to wood decay.

\section{Iron-Manganese Crusts}

The presence of this motte, on the edge of the flat polder landscape, generated an irregular raising of the local groundwater table in the central part of the hill. This more or less suspended, water-saturated pocket has only slight contact with the permanent water table present in the original soil buried under the hill. The outer limit of this anoxic area within the hill is characterized by the presence of an essentially continuous iron-manganese crust that shows little relation to the sedimentary boundaries of the successive raising phases of the motte. This particular soil moisture pattern generated a series of postdepositional migrations/accumulations of clay and soluble compounds of iron, phosphorous, sulfur, manganese, and organic matter in the hill. The morphology of the successively dumped layers and occupation levels is strongly influenced by these migration and accumulation processes.

The iron-manganese crusts locally follow the contact between successive depositional layers, but elsewhere they cross the motte layers, sometimes vertically to the boundaries of the depositional layers. In places, the crust is composed of amorphous, reddish forms of iron and manganese, impregnating the matrix and all kinds of mineral fragments present at the water table limit. The crust can also be made up of poorly crystallized goethite droplets and manganese. On the reduced side, the crust is associated with vivianite in various stages of alteration and with wellpreserved organic matter remains. The micromorphological observations reveal that some parts of the crust coincide with linear clay accumulations situated in a completely reduced area, as evidenced by the presence of vivianite in and around the clay crusts. The clay in this crust is probably associated with iron.

The microstratigraphy of these features seems to indicate that some clay first migrated and accumulated in microbands. The concomitant change in porosity probably created a strong gradient in oxidoreduction potential which generated the precipitation of iron and manganese over a short distance of only a few millimeters.

This iron-manganese crust then further trapped the percolating rainwater in the central part of the motte hill, resulting in a zone of permanently intense reducing conditions. The iron of the crust is mostly amorphous, but can vary in color, shape, and degree of concentration. Through the optical microscope, it is not always easy to differentiate yellowish amorphous forms of altered vivianite, iron oxide and decomposed organic residues (Figure 12). Microprobe analysis of these orange/yellowish, anisotropic, radiated crystallizations (Table IV) indicates a dominance (in various proportions) of carbon, phosphorous and iron (Figure 13). The carbon in this analysis reflects the crystic resin-impregnating medium. The quantity of iron increases where the color hue becomes redder and the iron is always associated with phosphorous. Such iron/phosphorus (Fe-P) accumulations are interpreted as various stages of formation/degradation of vivianite (Landuyt, 1990; Poethsch, 1996). These pedo-features are observed throughout the reduced part of the motte and result from the postburial diagenesis rather than the pedostratigraphic processes.

\section{CONCLUSIONS}

The micromorphological research confirmed the hypotheses of which possible origin of the earth was used to construct the motte hill. The three types of original soil that were excavated and used to raise the hill surface are the Polder Soil, the Gleysol of the Low Upland, and the Albeluvisol of the High Upland. 
The presence or absence of diatoms makes it possible to distinguish the origin in the Polder area or Tertiary upland substratum of the clayey fragments that are scattered in some parts of the hill. The presence of Polder sediments in the mussel shells of the first construction phase allows the proposal of a particular sequence for raising the motte surface, starting with the dumping of kitchen waste into the ditch, followed by the use of the sediments from the ditch bottom. In the field it was impossible to detect the origin of the earth used during the last construction phase (CP8). The thin sections point to the upland Albeluvisol. Special attention was paid to the possible migration processes related to the various stability phases of the motte evolution. The few millimeters thick layers of construction in subphase CP7b are fine strata related to sorted sheet wash deposition. They are not related to clay migration. Elsewhere, however, and particularly in the sediments of construction subphase CP7a, numerous dusty clay-humus accumulation fibers were observed, probably related to a period with strong precipitation during a halt in the construction phase.

This conclusion concurs absolutely with the evidence of sheet wash observed in CP7b (see previous paragraph). The clay-humus migration bands that were observed in the field at the level of the last construction deposits (CP8) correspond in fact to iron-phosphorous accumulations. These are probably related to past periodic reducing conditions within the motte at this level. The process was most likely enhanced by the low permeability of the dumped earth and by the input of organic matter and dung from the grassland and the grazing cattle. The microscopic study provided basic information on the occupation layers. Several (OL1, OL2, OL8) were cultivation layers, containing traces of fertilization with organic manure from ditch bottoms (OL1 and OL2) and with material from the house and kitchen waste, such as charcoal, pot sherds, and bone fragments.

Several trampling layers (OL3, 4, and 5) were recognized in the field. The micromorphology shows evidence of at least periodically bare and humid surfaces (dusty coatings, diatoms, statospores), which could confirm the field diagnostic of enclosures into which cattle were periodically herded, probably during the night. OL6 and 7, richer in anthropic artifacts such as charcoal and the addition of various types of organic material, are probably related to longer periods of stabilization, but stalling activities have also been important here.

The study of the thin sections gave a much more comprehensive insight into the various post-depositional processes active throughout the motte hill. The thin sections allow a much better characterization of the various types of redoximorphic accumulations, such as the iron-manganese crusts, which often appear to be related to iron-phosphate accumulations. The olive-colored mottles, frequently observed in the field, often appear to represent various degradation phases of vivianite. This shows that the reducing conditions within the hill were more pronounced in the past than at present. Many of the soil characteristics studied are directly or indirectly related to various types of human activities. Others, however, are the result of pedogenetic processes. There are numerous Fe-P accumulations observed all along the profile, lacking logic with the CP or LF development, but mainly present in the reduced area. These clearly show that it is very difficult to interpret the morphological and chemical characteristics of these motte profiles without a preliminary study of the numerous internal postdepositional depletion, migration and accumulation processes. Micromorphology was the first necessary step in the laboratory characterization of several of the accumulation features. Except for the input of percolating rainwater and the dung, manure, or fertilizer applied to its surface, there is no lateral input in this isolated, well-dated hill. As such it can be considered as a laboratory and an exhibition for research in soil science. There is a need for further opportunities for continuing this type of research, which provides both archaeologists and soil scientists with basic information in their respective disciplines.

The equipment used for the preparation and observation of thin sections was obtained through a research grant of the Belgium National Science Foundation allocated to Dr. Roger Langohr. A Gebhardt's study was carried out through a postdoctoral fellowship awarded by the European Community Research Program on Human and Capital Mobility Package, from February to July 1993. This study would not have been possible without the collaboration of the archaeologist C. Vanthournout, responsible for the Werken excavation. Thanks are also due to D. Marguerie, Laboratoire d'Anthropologie, Universite' de Rennes 1 (France) for determination of wood fragments on the thin sections, to B. Van Vliet-Lanoe“, Ge'osciences, Universite' de Rennes 1 (France), for help in Fluomicroscopic determination of the organic matter, and to Dirk Dedecker (Laboratory for Micropedology, Gent) for his help in microprobe analysis. Last but not least, we would like to thank Richard Macphail (Institute of Archaeology, London, United Kingdom), who discussed with us the micromorphological results.

\section{REFERENCES}

Bakels, C.C. (1988). Pollen soils in the province of North Brabant, the Netherlands. In W. Groenmanvan Waateringe \& M. Robinson (Eds.), Man made soil, BAR International Series 410 (pp. 35-54). Oxford.

Bastiaens, J. (1994). Plaggenbodems in de Antwerpse Kempen. Ko“ ninklijk AardrijkskundigGenootschap van Antwerpen, Jaarboek, $100,24-40$. Bastiaens, J., \& Van Marik, J.M. (1994). Bodemsporen van beddenbouw in het zuidelijk deel van het plaggenland. Historisch Geografisch Tijdschrift, 12, 81-90.

Brochier, J.E. (1995). Estiudi geoarquelo` gic dels dipo`sits holocens de la Balma de la Margineda: Capes de 1 a la 6. In J. Guilaine et al. (Eds.), Les excavacions a la Balma de la Margineda (1979-1991) (pp. 56-90), Andora: Edicions del Govern d'Andora.

Bullock, P., Fedoroff, N., Stoops, G., Tursina, T., \& Babel, U. (1985). Handbook for soil thin section description. Wolverhampton, United Kingdom: Waine Research.

Courty, M.A., Goldberg, P., \& Macphail, R.I. (1989). Soils and micromorphology in archaeology. Cambridge Manuals in Archaeology. Cambridge: Cambridge University Press.

Deflandre, G. (1936). Les flagellés fossiles. Aperçu biologique et paléonthologique. Rôle géologique. Paris: Hermann.

FAO (1998). World reference base for soil resources (pp. 84, 88). World Soil Resource Reports. Rome: FAO.

Gebhardt, A. (1994). Mez Notariou (Ouessant, Finistère) Rapport d'étude micromorphologique, Rennes: Laboratoire d’Anthropologie, Préhistoire, Protohistoire et Quaternaire Armoricain, UPR403, CNRS.

Gebhardt, A. (1995). Le Camp de St. Symphorien (Paule, Côtes d'Armor) Rapport d'e'tude micromorphologique. Rennes: Laboratoire

d’Anthropologie, Préhistoire, Protohistoire et Quaternaire Armoricain, UPR403, CNRS. 
Gebhardt, A., \& Langohr, R. (1996), Archaeo-pedological study of post-occupational processes from a medieval motte in Werken (West-Flanders, Belgium). In M. Colardelle (Ed.), L'homme et la nature au Moyen-Age, Actes du Ve Congrès International d'Arche'ologie Me' die' vale (Grenoble) (pp. 212- 214). Paris: Errance.

Gebhardt, A., Marguerie, D., \& Hunot, J.Y. (1995). Meules de charbonnier et archéomeétrie: Problématique, méthodologie et premiers résultats. In L’Archéométrie dans les pays Européens de Langue Latine. Programme et résumeés (p. 119). Peérigueux, April 26-29. GMPCA.

Langohr, R. (1991). Soil characteristics of the Motte of Werken (West Flanders, Belgium). In J. Tauber (Ed.), Methoden und Perspektiven der

Archäologie des Mittelalters, Tagungsberichte zum interdisziplinären Kolloquium, September 1989, Liestal, Switzerland (Archa“" ologie und Museum, Heft 020, pp. 209-223). Berichte aus der Arbeit des Amtes für Museen und Archäologie des Kantons Baseeland.

Landuyt, C.J. (1990). Micromorphology of iron mineral bog ores of the Belgian Campine. In L.A. Douglas (Ed.), Soil micromorphology, a basic and applied science. Developments in soil science (Vol. 19, pp. 289-294). Amsterdam: Elsevier.

Macphail, R.I., \& Cruise, G.M. (in press). The soil micromorphologist as team player: A multianalytical approach to the study of European microstratigraphy. In P. Goldberg, V. Holliday, \& R. Ferring (Eds.), Earth science and archaeology. New York: Plenum.

Pape, J.C. (1970). Plaggen soils in the Netherlands. Geoderma, 4, 229-256.

Poethsch, Th. (1996). Mineralogical and micromorphological characteristics of the soils of an archaeological excavation in the Elbmarsch of Germany. In Soil Micromorphology, 10th International Working Meeting on Soil Micromorphology, Moscow, Russia, July 8-13 (p. 152). Soil Survey Staff (1998). Keys to soil taxonomy, 8th ed. (p. 326). Washington, DC: U.S. Department of Agriculture, Natural Resource Conservation Service.

Vanthournout, C. (1991). The "Hoge Andjoen” Motte at Werken-Kortenmark mode of construction, function and chronology (with a contribution by Mark van Strydonck). In J. Tauber (Ed.), Methoden und Perspektiven der Archäologie des Mittelalters, Tagungsberichte zum interdisziplinären Kolloquium, September 1989, Liestal, Switzerland (Archa“ ologie und Museum, Heft 020, pp. 187-207). Berichte aus des Arbeit des Amtes für Museen und Archäologie des Kantons Baseeland.

Velain, C.H. (1878). Etude microscopique des verres re' sultants de la fusion des cendres de graminées. Bulletin de la Sociéteé Française de Minéralogie, 1, 113-125.

Verhulst, A. (1990). Précis d'histoire rurale de la Belgique, Brussels.

Youngblood, E., Frederiksson, B.J., Kraut, F., \& Frederiksson, K. (1978). Celtic vitrified forts: Implication of a chemical-petrological study of glasses and source rocks. Journal of Archaeological Science, 5, 99-121. 


\begin{tabular}{|c|c|c|}
\hline \multicolumn{2}{|l|}{ Field Descriptions } & Microfabric \\
\hline $\begin{array}{l}\text { Low Upland Soil } \\
\text { (Gley-sol) }\end{array}$ & $\begin{array}{l}\text { A: dark grayish brown (10YR 3/2) moderately humic very fine sandy. } \\
\text { E: iron-depleted horizon. } \\
\text { Bg: strongly hydromorphic horizon. } \\
\text { Cg: homogeneous light yellowish brown } \\
\text { (10YR 6/4) fine sandy subsoil; perma-nently reduced. }\end{array}$ & $\begin{array}{l}\text { A: dark-brown humified organic pellety sediment; phytoliths, well } \\
\text { preserved plant fragments }(0.1-1 \mathrm{~cm}) \text {, diatoms, strongly decomposed } \\
\text { organic fragments at the bottom. Bg: brown-orange/yellowish Fe-P } \\
\text { accumulations. } \\
\text { Cg: fine sand ( } 150-250 \mathrm{~mm}) \text { with hydromorphic reticulated clay } \\
\text { fragments; many Fe-P accumulations locally associated with iron crust; } \\
\text { diatoms, urchin } \\
\text { needles, shell fragments. }\end{array}$ \\
\hline $\begin{array}{l}\text { The High Up- } \\
\text { land Soil (Al- } \\
\text { beluvi-sol) }\end{array}$ & $\begin{array}{l}\text { A: humic loamy sand very dark grayish brown to dark brown (10YR3/2.5). } \\
\text { E: yellowish brown (10YR5/4) fine sand with thin iron/clay eluvial horizon. } \\
\text { Bt: strongly fragmented textual B horizon, rich in clay and iron, with light } \\
\text { coloured iron-and clay depleted tongues and pockets. } \\
2 \mathrm{C} \text { : light yellowish brown to light olive brown soil (10YR 5.5/4), developed on } \\
\text { the Tertiary clayey substratum } \\
\text { and covered by the Pleistocene fine and loamy fine sand. }\end{array}$ & $\begin{array}{l}\text { A: fine/coarse sand mixed with organic matter; fine dusty clay } \\
\text { accumulations, dusty fibrous matrix; phytoliths, charcoal, diatoms. } \\
\text { E: less abundant organic matter. } \\
\text { Bt: fine sand ( } 150-250 \mathrm{~mm}) \text { more/ less aggregated; small Bt fragments } \\
\text { covered by few fine dusty coatings; strongly ferru- } \\
\text { ginized brown-red clay; few fragments of humic horizons. } \\
\text { 2C: coarse sand + fine limpid clay coatings; strongly ferruginized Fe-P } \\
\text { accumulations; } \\
\text { round, pure glauconitic clay fragments; very dusty coatings; no diatoms, } \\
\text { no phytoliths, no organic matter. }\end{array}$ \\
\hline
\end{tabular}

Table I. Characteristics of the two natural Upland Soils.

\begin{tabular}{|c|c|c|}
\hline Layer & Field Description & Micromorphological Description \\
\hline $\begin{array}{l}\text { OL9 } \\
50 \mathrm{~cm}\end{array}$ & $\begin{array}{l}\text { Very dark grayish brown (10YR3/2) homogeneous horizon; } \\
\text { irregular lower boundary; abundant faunal activity; uniform } \\
\text { yellowish brown (10YR } 5 / 4 \text { ) deeper horizon }\end{array}$ & $\begin{array}{l}\text { Upper part with very organic well-developed, pellety structure, traces of fresh roots in } \\
\text { biogaleries and abundant phytholiths; much less organic with very few P/Fe impregnations } \\
\text { in the lower part }\end{array}$ \\
\hline $\begin{array}{l}\text { CP8 } \\
110-120 \mathrm{~cm}\end{array}$ & $\begin{array}{l}\text { Loamy sandy texture and some fragments of the horizons } \\
\text { de-scribed in CP5 }\end{array}$ & Very sandy groundmass, rounded quartz, feldspars, glauconite, very poor in matrix \\
\hline $\begin{array}{l}\text { OL8 } \\
12-16 \mathrm{~cm}\end{array}$ & $\begin{array}{l}\text { Similarities with the original soil, } \\
\text { dark brown to dark grayish } \\
\text { brown (10YR 2.5/2); smooth and sharp lower boundary; } \\
\text { some small worm galleries; little char- } \\
\text { coal, bricks and baked earth frag- } \\
\text { ments; uncompacted. }\end{array}$ & Not sampled \\
\hline $\begin{array}{l}\mathrm{CP} 7 \\
200 \mathrm{~cm}\end{array}$ & Similar to $\mathrm{CP} 5$, with fragments of all horizons & $\begin{array}{l}\text { 7a: coarse homogeneous sand with yellowish rounded clay fragments; fine limpid and dusty } \\
\text { clay coatings aggre-gates; small charcoal fragments } 7 \mathrm{~b} \text { : fine and coarse sand sorted in } \\
\text { irregularly thin bands ( } 500 \mathrm{~mm} \text { ) with Fe-P faccumulations; some dusty clay coatings; glass } \\
\text { slags } 7 \mathrm{c} \text { : heterogeneous sand; phytolith-rich fibrous organic matter, very fine char-coal, } \\
\text { sherd and bone fragments; mas-sive Fe-P accumulations or } \\
\text { bands; sediment with less humic top and more limpid clay intergrain coatings; humic } \\
\text { intergrain accumulations and fragments of strong iron impregnated Bt }\end{array}$ \\
\hline $\begin{array}{l}\text { OL7 } \\
20-30 \mathrm{~cm}\end{array}$ & Similar to OL6 & $\begin{array}{l}\text { Fine sand with few coarse quartz and rounded glauconite fragments; well developed dusty } \\
\text { coatings, abundant Bt fragments; abundant Fe-P impreg-nations; anthropogenic towards the } \\
\text { dwelling (dusty groundmass, fine charcoal); puddle-type finely layered sedimentation with } \\
\text { abundant phyto-liths, Chrysophyceae statospores, charcoal and vegetal fragments, no } \\
\text { diatoms }\end{array}$ \\
\hline $\begin{array}{l}\text { CP6 } \\
15-20 \mathrm{~cm}\end{array}$ & Same as CP5 (C) soil & Same as CP5 (C) soil \\
\hline $\begin{array}{l}\text { OL6 } \\
2-6 \mathrm{~cm}\end{array}$ & $\begin{array}{l}\text { Very compact; moderately humic layer, very few traces of } \\
\text { small earthworm activity; some trampling features. }\end{array}$ & $\begin{array}{l}\text { Dark organic matter accumulations; abundant very fine dusty coatings; sherds, shell } \\
\text { fragments, more or less charred wood fragments. }\end{array}$ \\
\hline $\begin{array}{l}\text { CP5 } \\
140 \mathrm{~cm}\end{array}$ & $\begin{array}{l}\text { (C) fine sand, loamy sand and a few clayey clods }(2 \text { to } 5 \\
\mathrm{cm}) \text {. (Bt) all types of fine sandy loamy clods }(, 3-10 \mathrm{~cm}) \\
\text { strong brown ( } 7.5 \mathrm{YR} 5 / 8 \text { ) to light olive gray }(5 \mathrm{Y} 6 / 2) \text { ) fine } \\
\text { limpid clay coatings cov-ered by few fine dusty coatings. (E) } \\
+ \text { small (A) and (Bt)fragments } \\
\text { (A) finely crushed organic matter with fragments }(, 1 \mathrm{~cm}) \text { of } \\
\text { very fine dusty clay accumulations; fibrous groundmass } \\
\text { aspect }\end{array}$ & $\begin{array}{l}\text { Fragmented elements of }(C) \text { (see Table I) } \\
\text { Fragmented elements of }(B t) \text { (see Table I) } \\
\text { (E) + big very organic fragments (see } \\
\text { Table I) } \\
\text { (A) + finely crushed organic matter; } \\
\text { some diatoms very fine charcoal frag- } \\
\text { ments; few glass slags (see Table I) }\end{array}$ \\
\hline $\begin{array}{l}\text { OL5 } \\
15-20 \mathrm{~cm}\end{array}$ & Similar to OL4 & Less organic; some Fe-P coatings and impregnations \\
\hline $\begin{array}{l}\text { CP4 } \\
30-40 \mathrm{~cm}\end{array}$ & Similar to Low Upland Soil & Similar to CP1 \\
\hline $\begin{array}{l}\text { OL4 } \\
5-10 \mathrm{~cm}\end{array}$ & $\begin{array}{l}\text { Similar to OL } 1 \text {; traffic pan and amorphous light yellowish } \\
\text { organic matter infilling the pores }\end{array}$ & $\begin{array}{l}\text { Similar to OL3; less pellety; dark organic coatings; abundant phytoliths; dusty and limpid } \\
\text { clay coatings in pores; some Fe-P crust and coatings under the "wavy" structure; more or } \\
\text { less fresh organic matter fragments }\end{array}$ \\
\hline $\begin{array}{l}\text { CP3 } \\
30-40 \mathrm{~cm}\end{array}$ & Similar to Low Upland Soil & Similar to CP1 \\
\hline $\begin{array}{l}\mathrm{OL} 3 \\
3-10 \mathrm{~cm}\end{array}$ & $\begin{array}{l}\text { Very dark humus compounds; very } \\
\text { sharp continuous and smooth up- } \\
\text { per limit; high compaction; traces } \\
\text { of trampling }\end{array}$ & $\begin{array}{l}\text { Slightly birefringent reticulated ground- } \\
\text { mass; dark humiferous (strongly de- } \\
\text { cayed organic matter); pellety } \\
\text { rounded peat fragments; diatoms; well-sorted coarse/fine fraction; "wavy" orientation; pyrites } \\
\text { in pud- } \\
\text { lling features; some fragmented char- } \\
\text { coal; blue vivianite; northern part } \\
\text { nonorganic }\end{array}$ \\
\hline $\begin{array}{l}\text { CP2 } \\
30-40 \mathrm{~cm}\end{array}$ & $\begin{array}{l}\text { Homogeneous light yellowish brown (10YR6/4) fine sand } \\
\text { like; fragments of OL1 horizon }\end{array}$ & Similar to CP1 \\
\hline $\begin{array}{l}\mathrm{OL2} \\
10-15 \mathrm{~cm}\end{array}$ & Similar to the original Low Upland Soil & $\begin{array}{l}\text { Homogeneous sand; brownish isotropic groundmass; pellety organic matter; isotropic brown } \\
\text { reddish rounded Fe-P fragments }(, 1 \mathrm{~cm}) ; \text { fine porosity; statospores; rounded daub } \\
\text { fragments }(250 \mathrm{~mm}-2 \mathrm{~mm}) \text {; nonbirefringent glass slags altered in wavellite; aniso-tropic } \\
\text { non birefringent slightly fluo-rescent reddish/yellowish Fe-P accu-mulations; crystallized blue } \\
\text { vivianite in reduced area }\end{array}$ \\
\hline \multirow[t]{2}{*}{$\begin{array}{l}\text { CP1 } \\
30-40 \mathrm{~cm}\end{array}$} & $\begin{array}{l}\text { Similar to the original Low Upland Soil with more biological } \\
\text { activity (worms and moles) }\end{array}$ & $\begin{array}{l}\text { Rounded quartz/glauconite sand }(0.5-0.1 \mathrm{~mm}) \text {, brown-reddish/black, enaulic/porphyric, } \\
\text { non-birefringent groundmass; porphyric reticulated rounded polder clay fragments }(1 \mathrm{~cm}) \\
\text { with many diatoms; mussel shells and micritic crystallizations. }\end{array}$ \\
\hline & Thick homogeneous very dark grayish brown (10YR 3/2); & Dark-brown humified organic and brown-orange/yellowish ferruginized fragments; no pellety \\
\hline
\end{tabular}




\begin{tabular}{|l|l|}
\hline OL1 & moderately humic; very fine sandy (A) hori- \\
& $\begin{array}{l}\text { zon; some worms and mole galleries; sharp limit between (A) } \\
\text { and (C) }\end{array}$
\end{tabular}

Table II. Field (from Langohr, 1991) and micromorphological soil and sediment description. CP: constructing phases; OL: occupation levels.

\begin{tabular}{|c|c|}
\hline Field Descriptions & Microfabric \\
\hline $\begin{array}{l}\text { Cultivation } 15-20 \mathrm{~cm} \text { thick, homogeneous, few earth worms and moles galeries, } \\
\text { sharp lower limit }\end{array}$ & Homogenized, rounded soil fragments, no pellety organization. \\
\hline Manuring Very dark layers, humiferous & $\begin{array}{l}\text { Fine charcoal, connected phytoliths, Chrysophicea statospores; isotropic Fe-P fragments (,1 } \\
\mathrm{cm} \text { ); rounded sherd and daub fragments, vitrified ash; nonpellety fresh plants fragments }\end{array}$ \\
\hline Farmyard Puddling and trampling features & $\begin{array}{l}\text { Puddling, trampling features; Chrysophicea statospores, phytoliths, diatoms; anisotropic } \\
\text { nonbirefringent slightly fluorescentreddish/yellowish Fe-P accumulations }\end{array}$ \\
\hline $\begin{array}{l}\text { Puddling Strong convolutions }(10-20 \mathrm{~cm}) \text {, mixing } \\
\text { the sediment layers }\end{array}$ & Little sorting of sand/dusty-clay along the "wavy" orientation. \\
\hline $\begin{array}{l}\text { Trampling Highly compacted traffic pan }(5-10 \mathrm{~cm}) \text {; heterogeneous amorphous } \\
\text { light yellowish organic matter filling the pores; sharp continuous limit }\end{array}$ & $\begin{array}{l}\text { Dark organic coatings; abundant phytoliths; dusty and limpid clay coatings in pores; some } \\
\text { Fe-P crust and coatings }\end{array}$ \\
\hline \multicolumn{2}{|l|}{ Anthropic artefacts } \\
\hline $\begin{array}{l}\text { Fragments of } \\
\text { Daub Small }(, 1 \mathrm{~cm}) \text {, rounded }\end{array}$ & $\begin{array}{l}\text { all rounded and scattered in the different soils } \\
\text { Heterogeneous clay with fine sandy component; parallel voids; filled with charred plants } \\
\text { fragments. }\end{array}$ \\
\hline Sherd Small $(, 1 \mathrm{~cm})$, rounded & Finer components than daub; very low porosity, no organic. \\
\hline Vitrified ash Not visible in the field & Colorless; isotropic; glasslike; round porosity \\
\hline Fireplace Crushed polder clay sediment in between very dark reddish layer. & $\begin{array}{l}\text { Upper layer with reddish clay clods; diatoms; large charcoal fragments, glass slags, very } \\
\text { organic burnt clay; lower layer with scattered fragmented charred twigs still in connection; } \\
\text { vitrified ash, small mamillated reddish droplets. }\end{array}$ \\
\hline Wooden Charcoal-like black layer, constructed board on a sandy layer & $\begin{array}{l}\text { One board of darkened oak; framboïdal pyrite in the reduced area; very dusty accumulation } \\
\text { within the oxidized sandy sediment. }\end{array}$ \\
\hline
\end{tabular}

Table III. Anthropogenic features.

\begin{tabular}{|l|c|l|}
\hline \multicolumn{2}{|c|}{ Field Descriptions } & \\
\hline $\begin{array}{l}\text { Fe-P } \\
\text { accumulation/ crust }\end{array}$ & Olive sediment impregnation & Light yellowish; isotropic; nonbirefringent; amorphous; slightly radiated structure. \\
\hline $\begin{array}{l}\text { Vivianite } \\
\text { Fe3(PO4)28H2O }\end{array}$ & Whitish powdery when reduced, deep blue when oxidized & Acicular, radiated blue crystals. \\
\hline Pyrite FeS2 & Black reddish spots, with framboïdal structure \\
\hline Siderite $\mathrm{FeCO} 3$ & $5-10 \mathrm{~mm}$ light reddish spots; cross under polarization \\
\hline
\end{tabular}

Table IV. Some diagenetic pedofeatures.

Fig. 1. Location of the site and the Flemish coast during the Roman Period (after Verhulst, 1990 and Vantournhout, 1991).

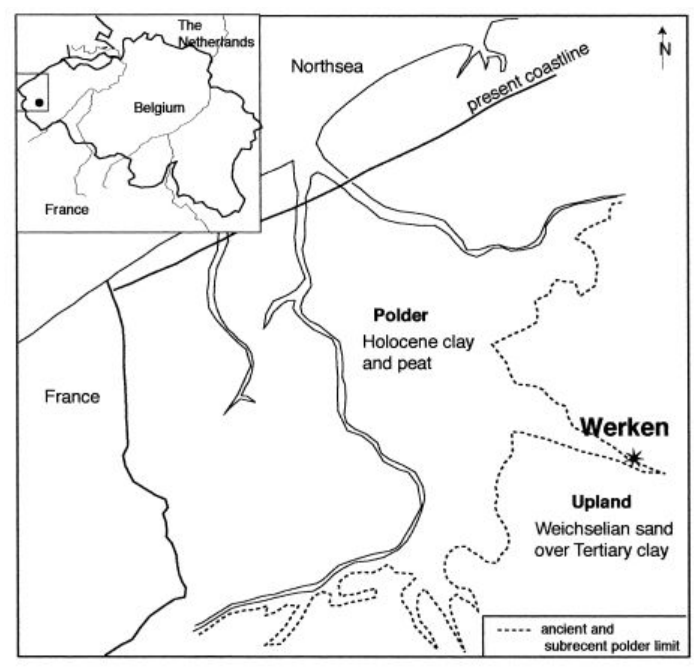


Fig. 2. General view of the excavated motte of Werken.
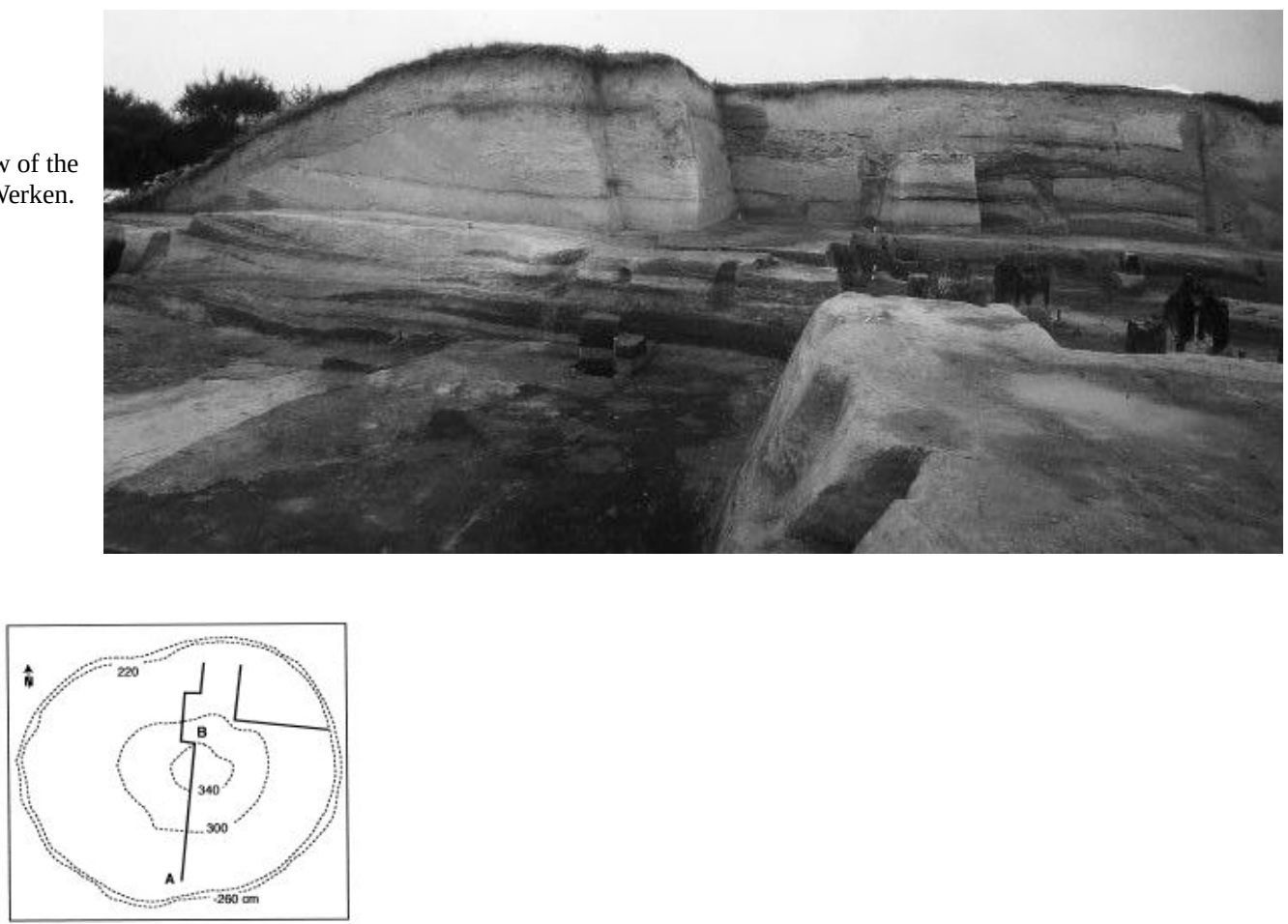

A

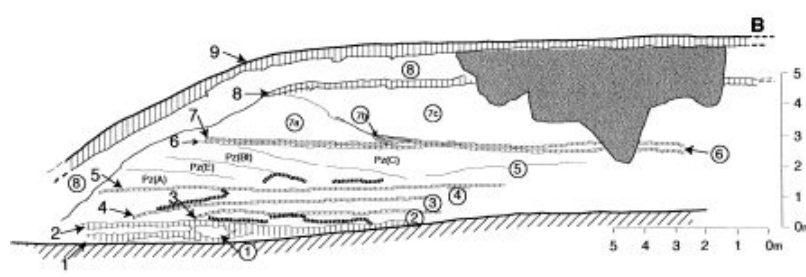

(1) construction phases, CP, 1 to 8

[III] occupation layers, OL, 1 to 9

hydromorphic iron-manganese accumulation crusts

[isturbance by $19^{\text {th }}$ century excavation

VI lower limit of the excavation.

Fig.3. (a) Plan of the motte with the location of the transect 3b (AB). (b) Stratigraphy of the Constructing Phases (CP) (in circles) and Occupation Layers (OP) (without circle) outside the dwelling (after Langohr, 1991).

Fig.4. Sediment of Construction Phase CP1. Fragments of peaty material rich in diatoms (D), with pellety organization of the organic matter and brown-reddish isotrope organic remains. PPL.

Fig.5. Sediment of Construction Phase CP1. Pellety organization of the organic matter with brownreddish isotrope plant remains, interpreted as fragments of peat soil. PPL.
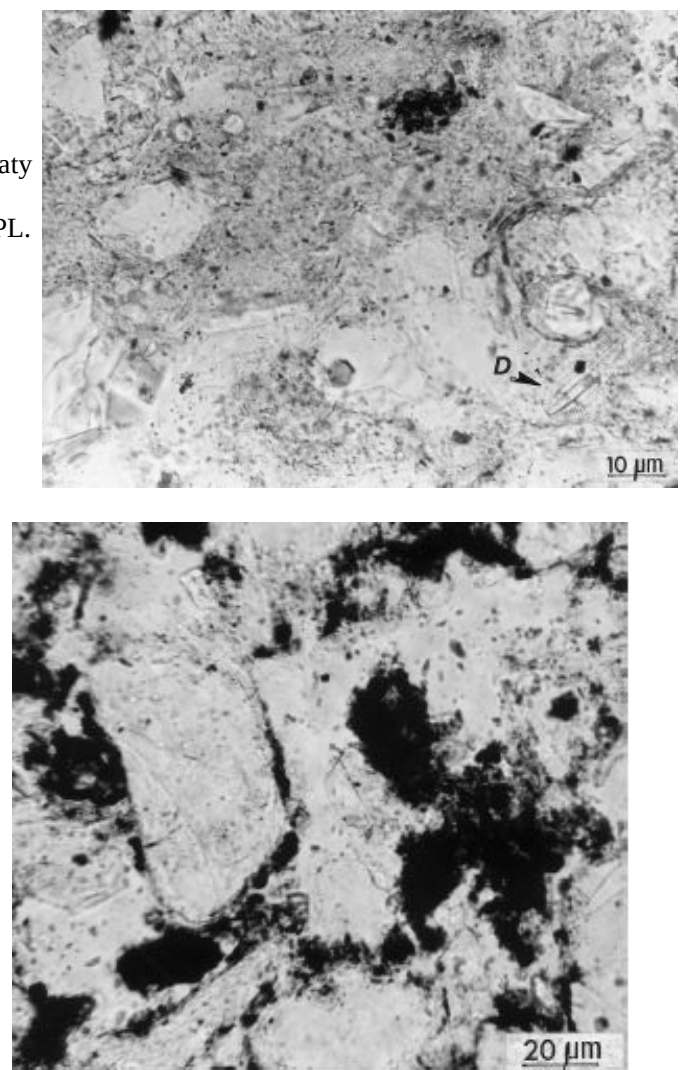
Fig.6. Occupation Layers OL1 and OL2. Highly organic layer, including scattered fragments of darkbrown humified organic material and some phytoliths (P). PPL.

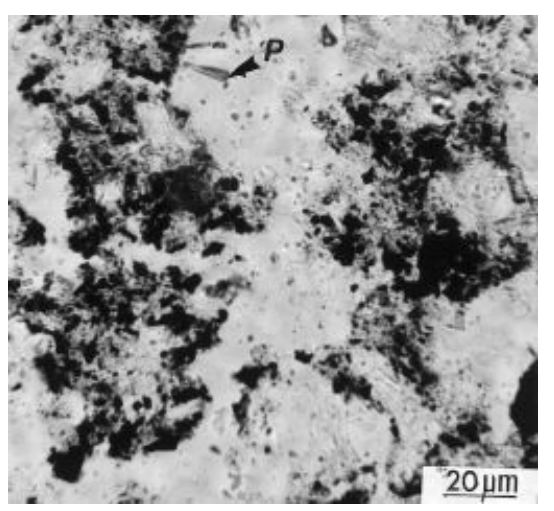

Fig.7. Occupation Layers OL1 and OL2. Charcoal fragments. Left—Corylus. Right—undetermined deciduous tree. PPL.

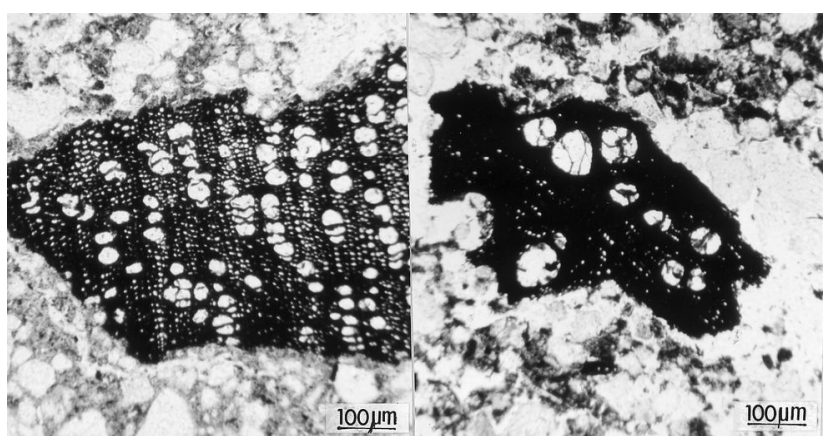

Fig.8. Fragment of daub composed of loamy, sandy earth containing plant fragments. The burned aspect of the latter may indicate the burning of a building. PPL

Fig.9. Fireplace at the level of a lateral living floo (not illustrated). Burnt earth with glasslike slag resulting from melting of opal phytoliths, in association with numerous charcoal fragments. PPL.
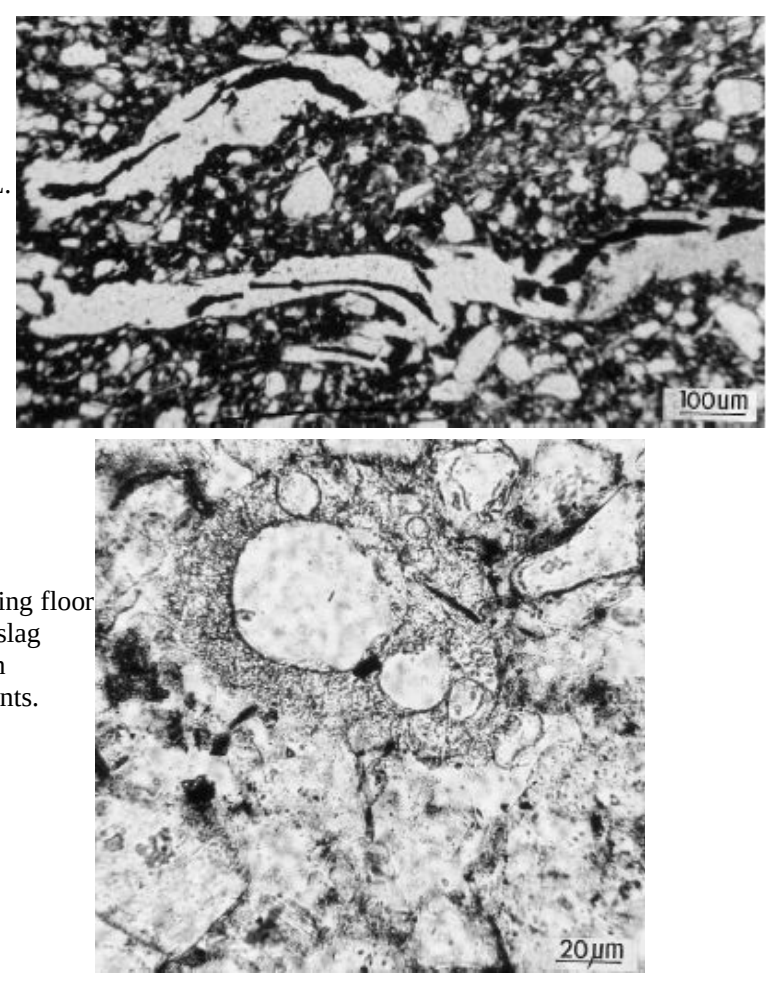

Fig.10. Occupation Layer OL4. Sorting of sediment in the trampling zone. PPL. Left-dusty clay coatings in the coarse fraction. Right-limpid clay coatings in the fine fraction.

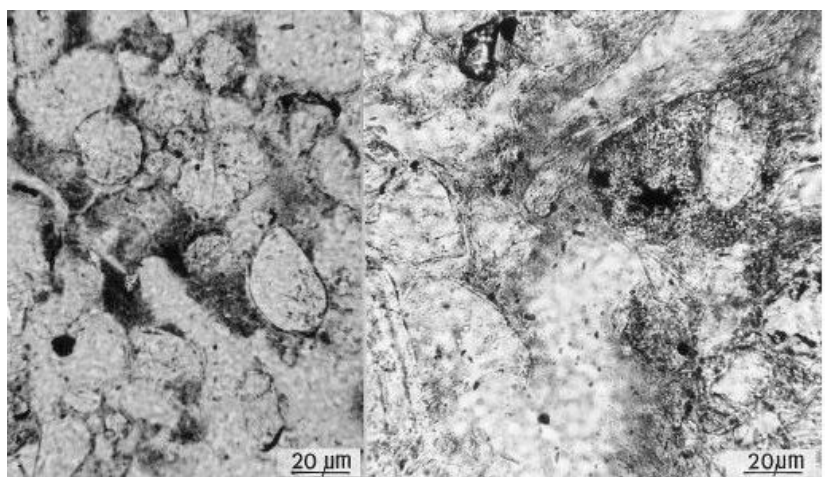


Fig.11. Occupation Layer of the lateral dwelling (not illustrated). Remnants of the same oak floor still clearly observable in reduced conditions and interpreted in the field as being slightly burned. In oxidized conditions, the presence of a dusty matrix and the absence of evidence of burning (charcoal, charred material), allow the conclusion that the charred aspect of the wood corresponds to a certain degree of decomposition and not to an effect of burning. Left-in oxidation conditions. Right-in reduction conditions.

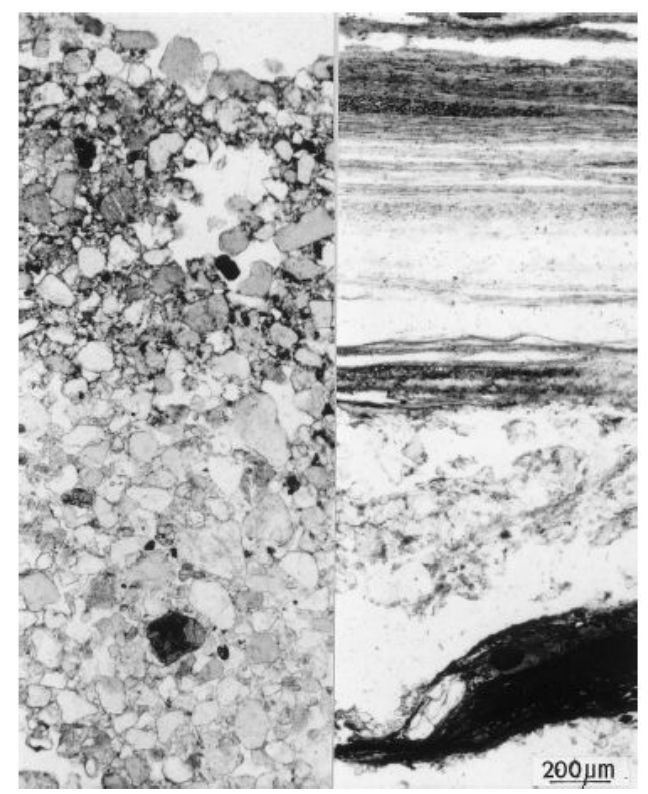

Fig.12. Occupation Layers OL1 and OL2. Yellowish anisotropic limpid features interpreted as various stages of iron phosphate accumulations.

Left-well-developed radial crystallization probably corresponding to the degradation of vivianite crystals. ( 1 and 2 correspond to the location of the microprobe analysis data). Right—no particular observable crystal structure. PPL.

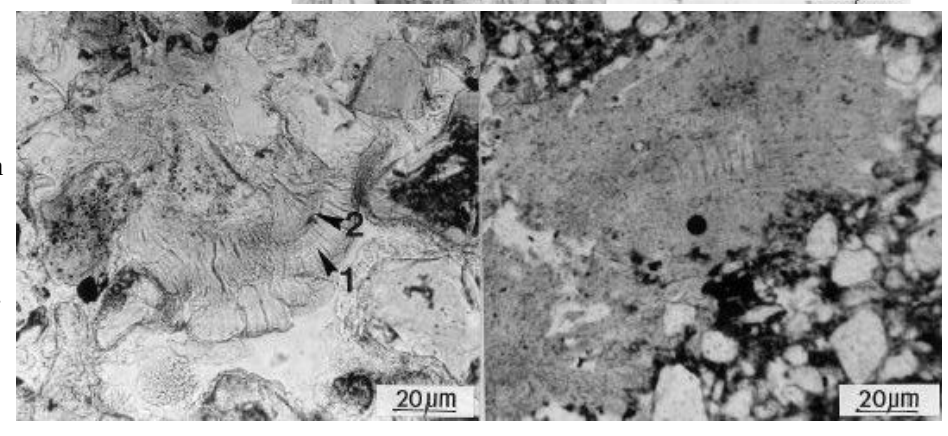

Fig.13. Microprobe analysis data from the yellowish anisotropic limpid (1. in the very light thick rim, 2. in the thin but denser rim.) (see Figures 12 and 13).
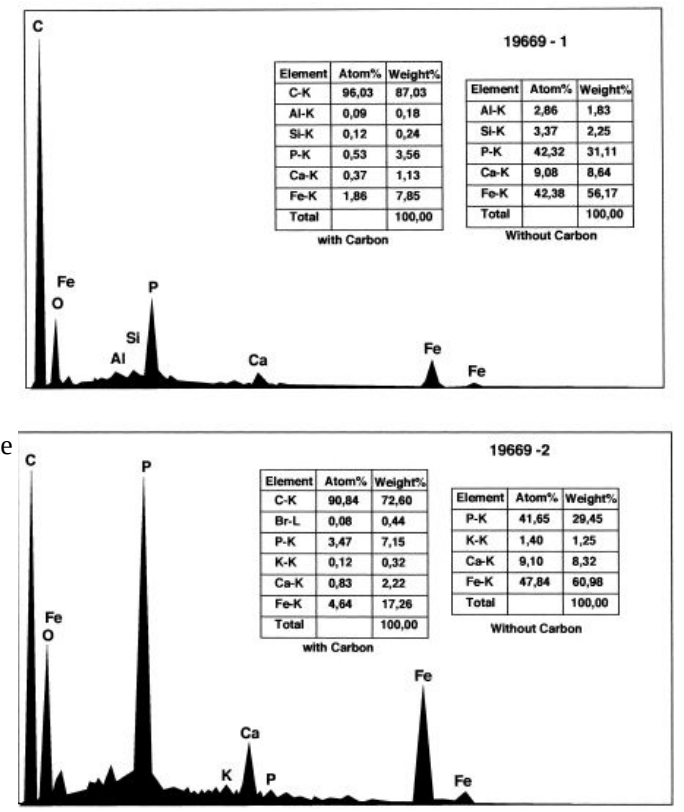